\title{
Consumer evaluations of store brands: effects of store image and product attributes
}

Citation for published version (APA):

Semeijn, J., van Riel, A. C. R., \& Ambrosini, A. B. (2003). Consumer evaluations of store brands: effects of store image and product attributes. METEOR, Maastricht University School of Business and Economics. METEOR Research Memorandum No. 015 https://doi.org/10.26481/umamet.2003015

Document status and date:

Published: 01/01/2003

DOI:

10.26481/umamet.2003015

Document Version:

Publisher's PDF, also known as Version of record

\section{Please check the document version of this publication:}

- A submitted manuscript is the version of the article upon submission and before peer-review. There can be important differences between the submitted version and the official published version of record.

People interested in the research are advised to contact the author for the final version of the publication, or visit the DOI to the publisher's website.

- The final author version and the galley proof are versions of the publication after peer review.

- The final published version features the final layout of the paper including the volume, issue and page numbers.

Link to publication

\footnotetext{
General rights rights.

- You may freely distribute the URL identifying the publication in the public portal. please follow below link for the End User Agreement:

www.umlib.nl/taverne-license

Take down policy

If you believe that this document breaches copyright please contact us at:

repository@maastrichtuniversity.nl

providing details and we will investigate your claim.
}

Copyright and moral rights for the publications made accessible in the public portal are retained by the authors and/or other copyright owners and it is a condition of accessing publications that users recognise and abide by the legal requirements associated with these

- Users may download and print one copy of any publication from the public portal for the purpose of private study or research.

- You may not further distribute the material or use it for any profit-making activity or commercial gain

If the publication is distributed under the terms of Article $25 \mathrm{fa}$ of the Dutch Copyright Act, indicated by the "Taverne" license above, 


\title{
CONSUMER EVALUATIONS OF STORE BRANDS: EFFECTS OF STORE IMAGE AND PRODUCT ATTRIBUTES
}

\author{
Janjaap Semeijn, Allard C. R. van Riel", Ana Beatriz Ambrosini \\ Faculty of Economics and Business Administration, Maastricht University, P.O. box 616, \\ 6200 MD Maastricht, The Netherlands
}

* Corresponding author. Tel.: +31 43388 3778, Fax: + 3143388 4918. E-mail address: A.vanRiel@mw.unimaas.nl 


\title{
Consumer evaluations of store brands: effects of store image and product attributes
}

\begin{abstract}
Store brands have grown in importance. Large numbers of products carrying a store label have been introduced in recent years, with varying degrees of success. It appears that retailers pay little attention to the multiple risks associated with adding new product categories to their store labels. In this study we investigate how attributes of store and product affect consumer evaluations of store branded products. A structural model is developed and tested, indicating the likelihood of success. Findings allow retailers to focus on product development in categories most compatible with their store's image.
\end{abstract}

Keywords: Store Brands, Store Image, Retailing. 


\section{Introduction}

The roles and importance of store brands have changed dramatically over the past decades. Cheap imitations of major brands and store and private brands are evolving into fullfledged alternatives, capable of competing successfully with manufacturer's brands on quality as well as on price (Quelch and Harding, 1996) and contributing substantially to profitability, store differentiation and store loyalty (Corstjens and Lal, 2000). Sales volumes and market shares of store brands, as well as their appeal to consumers have steadily increased (e.g. Dunne and Narasimhan, 1999; Nandan and Dickinson, 1994). Many retailers appear to view themselves increasingly as active marketers of their private brands, rather than passive distributors of manufacturers' brands (c.f. Richardson et al., 1994). Store brands can help retailers attract customer traffic and create loyalty to the store by offering exclusive product lines and premium products (Corstjens and Lal, 2000; Dunne and Narasimhan, 1999). In addition, store brands can help project a lower-price image for retailers, increase their bargaining power over manufacturers and producers of major national brands, and lead to increased control over shelf space (Narasimhan and Wilcox, 1998). Carrying store brands comes with numerous advantages, one of which is the relatively high gross margin, which can be $25 \%$ to $50 \%$ higher compared to manufacturer brands (Keller, 1993). This high margin mainly results from the more efficient marketing effort, the reduction of middlemen, and economies of scale obtained in distribution. Moreover, they present value to consumers by offering a combination of 'good quality' and 'better-value' products, and reinforce the retailer's name both on the store shelves and in consumers' homes (Fitzell, 1992; Richardson et al., 1996a).

Store brands are prominent in supermarkets. For instance, in 1999 private labels exceeded dollar earnings of manufacturers' brands in both food and non-food segments of U.S. supermarkets. According to the Private Label Manufacturers' Association (PLMA), one out of 
five items sold in American supermarkets, drug store chains and mass merchandisers is sold under a private or store brand. In the UK, the strongest private label market in Europe, store brands have a nearly $40 \%$ share of all grocery sales (Steenkamp and Dekimpe, 1997). This implies that some product categories are actually dominated by store brands (Baltas, 1997). Some analysts expect that by 2005 close to $50 \%$ of all EU grocery sales will be represented by the top ten retailers. Therefore, the cumulative power carried by these retailers and their store brands is significant (Lepir, 2001).

When searching for lower priced alternatives at the lower end of the market, it appears that consumers prefer the guarantee that a familiar store name brings rather than the risks associated with buying from a lesser-known manufacturer brand (Baltas, 1997). Store brands are becoming major brands in their own right with their own identities and quality images. They are increasingly seen as important sources of profitability (Ailawadi, 2001; Ailawadi and Harlam, 2002), which explains why many new product lines are being developed for them, and associated marketing efforts have significantly increased.

\subsection{Rationale for the study}

Supermarket chains have been consolidating their positions through mergers and acquisitions. With fewer and bigger players competing in markets, retailers need to carefully assess their strategies in order to gain market share. Developing a strong store brand can play an important role in this effort. However, a single store brand can be highly successful in some product categories while being unprofitable in others (Hoch and Banerji, 1993). Differences among product categories appear to be a cause of variance in store brand share both across markets and across retailers (Batra and Sinha, 2000; Dhar and Hoch, 1997).

For retailers, there are multiple risks associated with the introduction of new products under a private or store label. Store brands are typically umbrella brands, including various product categories. A negative experience with one product category can prevent consumers 
from buying private labels in other categories, and even erode customer confidence in the store as a whole (Thompson, 1999). The larger the number of categories marketed by an umbrella brand, the more negative the spill-over effects that occur (Sullivan, 1990). In some cases consumers could be driven to competing grocery stores. Retailers should therefore first assess the likelihood of acceptance of a new category under the store label. This assessment can be made by investigating consumer evaluations of store brands (Dick et al., 1996; Sethuraman and Cole, 1999) and assessing if and how store related factors (Richardson et al., 1994; Richardson et al., 1996b) and product category attributes (Batra and Sinha, 2000; Raju et al., 2001) affect this evaluation.

This paper is based on a study designed to develop a better understanding of the conditions leading to success when a new grocery product is added to a store's private label. Based on the findings, grocery retailers will be able to focus on lines most compatible with their respective store images. The problem statement guiding this study is:

Which factors affect the success of store brands in grocery retailing?

The following sub-questions were formulated:

1) How do retailer attributes affect consumer evaluations of a store branded product?

2) What is the role of product attributes in determining consumer evaluations of store branded products?

3) To what extent are the effects of product attributes on consumer evaluations of store branded products moderated by retailer attributes?

\subsection{Approach}

The article is structured as follows. First, existing literature is reviewed and a number of propositions are derived. These are summarized into a theoretical model. Secondly, the 
research model and design are shown. A presentation and discussion of the results follows. Next, the implications of these findings are discussed. Finally the limitations of the research and some suggestions for further research are presented.

\section{Store brands}

Store labels can take many forms. They can be umbrella brands encompassing many different types of products, range brands depicting a range of products, line brands uniting products with a unique concept within a range, and finally product brands (Kapferer, 1994). The positioning of the brand (e.g. premium, commodity) is a function of many different variables, such as the image of the store, quality of the products, and motivation of the retailer to invest in promotion (Davies, 1998; Kapferer, 1994).

Store brands prevail in categories like cosmetics and toiletries, clothes and grocery products. In some cases it is difficult to make a clear distinction between the store's private label and the store itself, since the store exclusively sells its own brands. This is the case with the clothing store Gap. In many other cases, the store brand is just another brand available in the store and competing with manufacturer's brands. This situation is typical for most grocery stores.

\subsection{Development of propositions}

One of the basic questions centers on if and how retailer attributes influence consumer evaluations of store brands. Although grocery stores are facing problems in differentiating themselves due to the lack of a perceived core product/service and the need to address the broadest possible range of consumers and purchase situations, Dick et al. (1995) observed that the store image functions as an important indicator of store brand quality for consumers. Store image is reflected in the store's physical environment (Richardson et al., 1996b), the overall quality of its merchandise, and perceived service quality (Baker et al., 1994; Zimmer and Golden, 1988). Consumers use these cues to form an overall evaluation that will affect their 
attitude toward the store as a whole and potentially towards its store brands. Several chains have shown that they can compete and outperform manufacturer branded products. Some examples are Harrods with its premium brands, Sainsbury and Tesco with relatively cheap, high quality product lines, and Aldi with its "no-frills" stores and a clear focus on basic products at a low price (Fitzell, 1992). Consumers will thus be affected in their buying decisions by their experiences with the retail environment and the level of service. Based on the arguments presented above, we expect:

\section{P1: There will be a direct positive relationship between perceived store image and consumer attitude towards store branded products.}

Apart from effects of the store image, it has also been hypothesized that perceived product attributes affect the attitude of the consumer towards merchandise sold under a store brand. Furthermore, it seems worthwhile to investigate the effect of the store image on these perceptions. Steenkamp and Dekimpe (1997, p. 927) state that "the power of a store brand, even for a powerful retailer, varies dramatically across product categories". Apparently even a strong store brand does not guarantee success for all product categories for all retailers. These differences have been related to the perceived risks associated with store brand purchases (Mitchell, 2001). By choosing among different brands, and depending on the degree of involvement with each product, consumers make trade-offs between the types and degrees of risk they perceive. The risks associated with the purchase of a product can assume different forms, but have traditionally been categorized into three groups, namely functional or physical, psychosocial, and financial risks.

Functional risk relates to the physical performance of the product. Functional risk is reflected in both category complexity and category quality variance. Product complexity is related to a consumer's perception of how difficult it is to manufacture a certain type of product - the perceived difficulty is based on different aspects, such as technology and 
ingredients. It is generally expected that category complexity and the perceived quality of the private label are inversely related, i.e., the higher the category complexity the lower the expected private label quality (DelVecchio, 2001). It is therefore expected that:

P2: Consumer attitude towards a store branded product is inversely related to the functional risk associated with the perceived difficulty for the retailer to produce that product.

At the same time, it is expected that consumers' perceptions of the retailer have a moderating effect on the perceived risk. Therefore:

P2a: The effect of store image on consumer attitude towards a store branded product is mediated by the functional risk associated with the perceived difficulty for the retailer to produce that product.

Psychosocial risk is associated with the consumption of the product and its symbolic aspects, such as beliefs and status (Batra and Sinha, 2000; DelVecchio, 2001). Psychosocial risk exists to the extent that the consumer believes that he/she will be negatively evaluated due to his/her product (brand) choice. Nonetheless, not all products are consumed in public situations, that is, other people might not be aware that someone possesses and uses a certain product, as it is not highly visible to others (Bearden and Etzel, 1982). It is generally accepted that the more visible or public a product category, the smaller the chance that a consumer will use a private brand, due to its low level of symbolic quality. Therefore, we expect an inverse relationship between usage visibility of the product (or "publicness") (DelVecchio, 2001) and consumer attitudes towards the store branded product:

P3: Consumer attitudes towards a store branded product are inversely related to the perceived psychosocial risk associated with the usage of the product. 
Again, it is expected that consumers' perceptions of the retailer have a moderating effect on the perceived risk. Therefore:

P3a: The relationship between store image and consumer attitude towards a store branded product is mediated by the perceived psychosocial risk of usage.

When substantial quality variance occurs within a product category, the likelihood of a consumer making the wrong purchase decision is increased. This would lead to the perception of financial risk. According to Hoch and Banerji (1993) store brands have a better chance to succeed in categories where their quality is high compared to national brands and where quality variability is low, i.e. competing brands do not vary much in terms of quality. The general expectation is that in product categories with large quality variability, store labels will appear at the lower level of the quality spectrum (DelVecchio, 2001):

P4: Consumer attitude towards a store branded product is inversely related to the perceived financial risk associated with quality variance in the product category.

The hypothesized relationships are summarized in the conceptual model represented in Figure 1.

\section{Please Insert Figure 1 About Here}

\section{Research design}

An experiment was designed in order to determine the structural relationships between store image, product attributes and consumer attitude towards store branded products. In this section, the selection of brands for the study will be motivated, followed by a description of the criteria for selecting the product categories. The methodology is then discussed in some detail. 


\subsection{The case study-three grocery stores in The Netherlands}

For convenience reasons we investigated our research questions in the grocery industry in The Netherlands. Private brand penetration is around $20 \%$ in this market (Wileman and Jary, 1997) while the three largest grocery chains account for more than $60 \%$ of total retail sales (Steenkamp and Dekimpe, 1997). For the present study three major and well-known grocery chains, Albert Heijn (AH), Edah, and Aldi were selected. The three selected chains vary substantially in features such as the physical design of the stores, the general merchandise assortment, the pricing strategy, and the amount and role of advertising.

\subsubsection{Albert Heijn}

Albert Heijn (AH) is owned by the 'Royal Ahold' group, the third largest player in the global retail industry, operating thirty different chains consisting of nine thousand retail stores in twenty-seven countries. AH is the largest grocery chain in the Netherlands, with more than two thousand three hundred outlets and a market share approaching 30\% (Dekimpe and Steenkamp, 2002). The stores share an attractive design, offer a broad assortment of quality products and brands, and carry a premium image. The overall price level is higher than at other chains. The AH stores sell approximately four thousand products under private labels - ranging from basic products such as milk and toilet paper to more elaborate and premium products, including ready-to-eat meals, 'gourmet' ingredients, and kitchen utensils. All private label products include the store name and logo on the packaging. In addition, the stores offer the Euroshopper brand - basic, everyday-use products at discounted prices -, which do not carry the store logo. Of the three stores investigated, $\mathrm{AH}$ has the largest advertising budget. This advertising is focused on promoting the store image and store brands, and includes a free monthly magazine. 


\subsubsection{Edah}

The Edah chain is part of the 'Laurus' group. Laurus operate 1200 outlets in the Netherlands, including the 'Konmar' and 'Super de Boer' stores. The group owns multiple chains in The Netherlands, Belgium and Spain, operating some 2400 grocery outlets altogether. Compared to $\mathrm{AH}$, Edah lacks the prestige image and comparatively high prices, without being considered a discount chain. Six hundred products are carried under the Edah private brand, carrying the name and logo of the store. Edah's focus on product innovation is not as accentuated as it is at AH. Nonetheless, the company claims to be similarly concerned with product packaging and presentation. Edah uses various channels to advertise the brand, such as TV, radio, leaflets, and newspapers. However, contrary to Albert Heijn, Edah promotes manufacturer brands in its advertising rather than products with the Edah label.

\subsubsection{Aldi}

Aldi is a German discount chain, and successful in even the most entrenched local markets in Europe (10 countries) and has been expanding more recently into the US and Australia. Aldi's objective is offering good quality products at an everyday low price (EDLP). The company maintains a low cost strategy: investments in store design, staff, or product packaging are kept to a minimum. Aldi avoids carrying products that duplicate similar products. Each Aldi store carries some one thousand products, with a focus on basic products and not on differentiation and innovation. With the exception of special temporary deals on bulk volumes of particular branded products, the chain exclusively carries private labels. However, Aldi tends not to use its own name or logo to identify its brands. Products or product groups generally carry a unique label. Aldi is not known to utilize much advertising in order to promote the store. The main media used are newspapers and the store leaflet presenting special offers, often more focused on the availability of temporary stock than on discounts. 


\subsubsection{Product selection}

The product categories used in our empirical study were selected based on availability and familiarity to consumers. The need for variance in the different risks associated with the purchasing decision, functional, financial and psychosocial, guided us further in selecting the following product categories: wine, toothpaste, potato chips, and canned tomatoes. The categories were classified as follows: The 'wine category' represents the highest psychosocial risk, as it has the highest level of usage visibility; it also symbolizes high functional risk because of the difficulty to produce wine and the consequences of the consumption of an inferior wine. It also represents a product category with a very high quality variance. Next comes the 'toothpaste category'. Toothpaste carries medium psychosocial risk since it is not often used in public situations; nonetheless, no one wants to be associated with bad/cheap hygiene products. Moreover, it scores high in functional risk because of health related consequences, and there is significant quality variance in the category. The 'potato chips' category can be classified as inexpensive (low financial risk), easy to produce (low functional risk) and as having low to medium psychosocial risk. And finally, the 'canned tomatoes' category can be seen as the simplest one with a low level of visibility (psychosocial risk) and very low level of functional risk - easy production and hardly any quality variance among brands.

\subsubsection{Questionnaire design}

A questionnaire was developed to test the model. The survey was administered online, as invitations to participate were sent to a mailing list of business students from a medium sized university in the Netherlands, and subsequently to other potential respondents. In the email and on the opening page of the online survey the basics of the research were explained. Filling out the questionnaire took on average between 15 to 20 minutes. The incentive of 
winning a DVD player was used to increase the number of participants. Respondents had to disclose their name and address in order to participate in the sweepstake.

The questionnaire consisted of 110 statements. Respondents were asked to indicate their agreement with these statements on 7-point Likert type scales (totally disagree to totally agree, very bad to very good, and very unlikely to very likely). The survey consisted of two parts: In the first part, measuring the store image, respondents had to evaluate the three chains. In the second part, the perceived psychosocial, functional and financial risks relating to various product categories, and the associated attitudes of the participants towards store branded products were measured for each of the three chains.

\subsubsection{Store image}

The variable store image was measured as a factor composed of seven items, adapted from previous research on store image (Baker et al., 1994; Birtwistle et al., 1999; Bloemer and de Ruyter, 1998; Mazursky and Jacoby, 1986) and retail service quality (Dabholkar et al., 1996). The items, as well as the associated factor loadings, are listed in Table A-1 in the appendix. The factor was obtained in a principal component analysis. Based upon the interpretation of the Scree test only one factor was identified, explaining $48 \%$ of the variance. A value of .846 was found for the KMO test and for Bartlett's test we obtained a value for Chi-Square of 3242,135 (d.f. $=21$, Sig. $=.000)$. Reliability was tested with Cronbach's test and a value of .82 was found for Alpha.

\subsubsection{Dependent variable}

The dependent variable, consumer attitude towards the store brand, was operationalized in accordance with previous studies in branding research (Aaker and Keller, 1990; van Riel et al., 2001), by averaging two measures: the perceived overall quality of the store brand ( $1=$ inferior, $7=$ superior $)$ and the likelihood of purchasing the store brand, 
assuming that the customer was planning a purchase in the product category $(1=$ not at all likely, 7 = very likely).

\subsubsection{Sampling}

One hundred and thirty-three participants filled out the questionnaire. Each respondent answered questions about three stores with four product categories resulting in a factorial design of 1596 cases $(3 \times 4 \times 133)$. The respondents included sixty-seven females and sixtysix males. The average age was between 20 and 24 years old $-68.1 \%$ of the respondents were in this age range. In addition, 8,8\% of the respondents were between 15 and 19 years old, $15.9 \%$ between 25 and 29 years, $1.8 \%$ between 30 and 34 years, and finally $5.3 \%$ of the sample was older than 34 years.

\section{Analysis and results}

\subsection{Testing the propositions}

The theoretical model to be tested can be represented by the following set of equations:

$$
\begin{aligned}
& \text { (1) } Y=\gamma_{1}+\beta_{1} I+\beta_{2} C+\beta_{3} V+\beta_{4} P+\varepsilon_{1} \\
& \text { (2) } C=\gamma_{2}+\beta_{5} I+\varepsilon_{2} \\
& \text { (3) } P=\gamma_{3}+\beta_{6} I+\varepsilon_{3}
\end{aligned}
$$

Where the variables are:

$\mathrm{Y}=$ consumer attitude towards the store brand,

$\mathrm{I}=$ store image

$\mathrm{C}=$ perceived difficulty for the retailer to produce the product (functional risk)

$\mathrm{V}=$ quality variance in the category (financial risk)

$\mathrm{P}=$ perceived social risk of using the store branded product

$\gamma=$ intercepts

$\varepsilon=$ error terms 
Before conducting the regression following equation (1) the data were investigated on a descriptive level. Selected descriptives are reported in Table 1. It appears that AH has the best and most consistent store image among participants: $\mathrm{AH}$ is followed by Edah and finally by Aldi. A look at the means of consumers' attitudes towards the store brand reveals that although $\mathrm{AH}$ attained the highest level, Edah and Aldi are at similar levels. These differences are clearly less pronounced than the ones between the different store images.

\section{Please Insert Table 1 About Here}

From this table it becomes obvious that the retailer sample is not homogeneous. It was therefore decided to first create correlation matrices for the three retailers separately, including all core constructs, with the primary purpose of obtaining insight in the data structure. These matrices are presented in Table 2.

\section{Please Insert Table 2 About Here}

Significant correlations exist between most of the variables, the highest level being between attitude towards the private brand and perceived financial risk in the $\mathrm{AH}$ and Edah samples, and between attitude towards the private brand and store image in the Aldi Sample. This observation is an indication that it may not be allowed to pool the data for the three retailers. Before any further techniques could be applied, parameter stability over the three store brands had to be verified. F-tests (Chow, 1960) were thus applied to regressions according to model (1) of various combinations of the three partial samples. For that purpose, two dummy variables were introduced with the following values: 
$D_{1}=1$ : Albert Heijn and $D_{1}=0$ : not-Albert Heijn

$D_{2}=1:$ Edah and $D_{2}=0:$ not-Edah

If $D_{1}=0$ and $D_{2}=0:$ Aldi

The new model becomes:

(4) $Y=\gamma_{1}+\gamma_{2} D_{1}+\gamma_{3} D_{2}+\alpha_{1}\left(D_{1} I\right)+\alpha_{2}\left(D_{2} I\right)+\beta_{1} I+\alpha_{3}\left(D_{1} C\right)+\alpha_{4}\left(D_{2} C\right)+\beta_{2} C+\alpha_{5}\left(D_{1} V\right)+$ $\alpha_{6}\left(D_{2} V\right)+\beta_{3} V+\alpha_{7}\left(D_{1} P\right)+\alpha_{8}\left(D_{2} P\right)+\beta_{4} P+\varepsilon$

This equation is automatically reduced to equation (1) if both $\mathrm{D} 1=0$ and $\mathrm{D}_{2}=0$, turns into equation (5) if $\mathrm{D}_{1}=1$, and into equation (6) if $\mathrm{D}_{2}=1$.

(5) $\mathrm{Y}=\gamma_{1}+\gamma_{2}+\gamma_{3}+\left(\beta_{1}+\alpha_{1}\right) \mathrm{I}+\left(\beta_{2}+\alpha_{3}\right) \mathrm{C}+\left(\beta_{3}+\alpha_{5}\right) \mathrm{V}+\left(\beta_{4}+\alpha_{7}\right) \mathrm{P}+\varepsilon$

(6) $\mathrm{Y}=\gamma_{1}+\gamma_{2}+\gamma_{3}+\left(\beta_{1}+\alpha_{2}\right) \mathrm{I}+\left(\beta_{2}+\alpha_{4}\right) \mathrm{C}+\left(\beta_{3}+\alpha_{6}\right) \mathrm{V}+\left(\beta_{4}+\alpha_{8}\right) \mathrm{P}+\varepsilon$

If there are no differences between the stores, this implies that $\alpha_{1}=\alpha_{2}=\alpha_{3}=\alpha_{4}=\alpha_{5}=\alpha_{6}=\alpha_{7}=$ $\alpha_{8}=0$. This is our $\mathrm{H}_{0}$. We can test this hypothesis with the Chow test statistic, defined as:

(7) $\frac{\left[R S S_{p}-\left(R S S_{1}+R S S_{2}\right)\right] / k}{\left(R S S_{1}+R S S_{2}\right) /\left(n_{1}+n_{2}-2 k\right)}$

This statistic has an $F$ distribution with $\left(\mathrm{k}, \mathrm{n}_{1}+\mathrm{n}_{2}-2 \mathrm{k}\right)$ degrees of freedom. $\mathrm{RSS}_{\mathrm{P}}$ equals the Residual Sum of Squares of the OLS regression on the pooled sample, $\mathrm{RSS}_{1}$ equals the Residual Sum of Squares of the regression on sample A and $\mathrm{RSS}_{2}$ equals the Residual Sum of Squares of sample B, where A and B represent the respective partial samples. Parameters $n_{1}$ and $n_{2}$ equal the number of observations in each partial store, and $k$ is the number of parameters.

First, a Chow test was conducted on the pooled sample of Albert Heijn and Edah. An F-value of .635 was obtained. This value is much smaller than 2.214 , the cut-off value of $F$ $(.05,5,1054)$. Therefore $\mathrm{H}_{0}$, stating homogeneity of the pooled sample (AH-Edah) was accepted. Furthermore a Chow test was conducted on the pooled sample of $\mathrm{AH}$ and Edah on the one hand, and Aldi on the other. The F-value we obtained, 4.82, was higher than 2.214, the cut-off

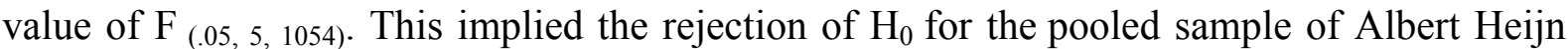


and Edah on the one hand and Aldi on the other. It was then decided to conduct the Chow test for each variable individually. The obtained $F$-statistics (see Table 3 ) indicated that parameters $\alpha_{1}, \alpha_{2}, \alpha_{3}, \alpha_{4}, \alpha_{5}, \alpha_{6}, \alpha_{7}$ and $\alpha_{8}$ were not equal to zero, implying that none of the $\beta$ values in the original model is stable over the three brands. The regressions and mediation tests were thus performed for both groups in order to tests the propositions separately. The two groups will be treated from now on as grocery stores (group with AH and Edah) and discount chain (the Aldi group). In order to investigate propositions 1, 2, 3 and 4, regression analyses were performed: attitude towards the store brand was regressed on the main variables, store image, functional risk, psychosocial risk and financial risk. The Chow test statistics for the separate variables as well as the results of these regressions are summarized in Table 3.

Please Insert Table 3 About Here

\subsection{Store image}

Our first proposition advocates a direct, positive and linear relationship between store image and attitude towards the private brand. The correlations found in our data (see Table 2) and the highly significant regression parameters found for this variable (see Table 3) confirm this for the grocery stores as well as for the discount chain, albeit to a different extent. Hence, as expected, store image perception influences consumers' judgment of store brand quality and proposition P1 is confirmed. The better a consumer thinks of a store the better he/she will evaluate the store's private label.

\subsection{Product attributes and associated risks}

Proposition 2 concerned the effect of perceived functional risk. A negative relationship was expected between the functional risk associated with a specific product and attitude 
towards that product carrying a store brand. Support for the existence of this relationship, in the form of the highly significant regression parameters (see Table 3), was found for grocery stores and discount chain and proposition P2 was confirmed for both groups.

Proposition 3 predicted an inverted relationship between the perceived psychosocial risk associated with using a product and the attitude towards that product carrying the store brand. Support for the existence of this relationship, in the form of the highly significant regression parameters (see Table 3), was again found for grocery stores and discount chain and proposition P3 was thus also confirmed for both groups.

Proposition 4 predicted a negative relationship between the perceived financial risk associated with purchasing a product in a category with large quality variance, and the attitude of the consumer towards products in that category carrying a store brand. A strong and significant regression coefficient was found for both groups, which confirms proposition P4.

In order to test the two mediation effects (Baron and Kenny, 1986), hypothesized in P2a and P3a, Sobel tests were conducted (MacKinnon and Dwyer, 1993; MacKinnon et al., 1995; Sobel, 1982) on the factors obtained for the independent variable (IV), the dependent variable (DV) and for the Mediators. See Figure 2 for a visualization of the mediating effect.

\section{Please Insert Figure 2 About Here}

The test statistic $z$ was calculated according to the following formula:

(8) $z=\frac{a * b}{\sqrt{\left(b^{2} * s_{a}^{2}+a^{2} * s_{b}^{2}+s_{a}^{2} * s_{b}^{2}\right)}}$

In this equation $a$ represents the unstandardized path coefficient of a regression of the IV (store image) on the Mediator (risk perception), $b$ and $c$ the unstandardized path coefficients 
of a regression of the mediator and the IV on the DV (consumer attitude). In a two-tailed Ztest of the hypothesis that the mediated effect equals zero in the population, a P-value of .000 and a Z-value of -5.52 (grocery stores) and a P-value of .536 and a Z-value of .62 (discount chain) were obtained in the case of functional risk. P-values of .000 and Z-values of -7.52 (grocery stores) and -6.40 (discount chain) in the case of psychosocial risk. Since \pm 1.96 is the critical value of the test ratio, it was concluded that there is indeed a mediation effect in all cases except for the discount chain in the case of functional risk. Apparently, the Aldi brand cannot reduce functional risk perception.

The suggested conceptual model explains the predicted effects in a convincing way for the grocery stores and is slightly less convincing for the discount chain. All terms were found significant and displayed the expected signs. The variables with the largest influence on consumers' attitude towards the store brand, in general, were store image and financial risk, both with large beta coefficients. A summary of the propositions and their status is presented in Table 4.

Please Insert Table 4 About Here

\section{Conclusion and Implications}

The purpose of this study was to explain the combined effects of retailer- and product attributes on consumer attitude towards store branded products in grocery stores and to make recommendations with respect to the most appropriate product categories for new product introduction. Effects for store image and three product attributes were hypothesized. The effects were measured in an empirical study including two grocery stores and a discount chain. 


\section{$5.1 \quad$ Store image and perceived private label quality}

Diversity across stores with respect to their retail strategy, store design and their commitment to serving their customers' needs results in variance in consumer's store image. Based on previous research (Richardson et al., 1994; Richardson et al., 1996b), a powerful effect was expected from store image on attitude towards the store brand. Direct and mediated effects were hypothesized. Both effects were observed in our study, so that store image must be considered an important predictor of attitude towards a store brand.

\subsection{Product attributes, related risks and attitude towards the store brand}

In previous studies, several product attributes had been identified as antecedents of private label success in specific product categories (DelVecchio, 2001): Complexity, quality variance, and visibility. In the present study, these product attributes have been related to consumer perceived risks associated with purchasing a product from a store brand. A negative effect of the perceived risks was predicted on consumers' evaluations of products under a store brand. It was also hypothesized that some risks can be neutralized by the perceived store image.

\subsubsection{Product complexity and functional risk}

Product complexity was associated with perceived functional risks of the product and the perceived difficulty for the store to manufacture it, as a result of required specialized technological knowledge. It was observed that the more difficult the consumer perceives it to be for a certain retailer to produce a specific product, the more likely it is that the consumer develops a negative attitude towards such a product carrying that retailer's store label. From the study it became clear that not all retailers were able to neutralize some of the functional risk with their store image. Since perceived after-sales service quality was an important indicator of the store image, and can be considered an important neutralizing factor of 
functional risk, it could be that the lack of confidence in the after-sales service in the discount chain was responsible for the absence of the predicted effect in this case.

\subsubsection{Visibility of product usage and psychosocial risk}

Our research confirmed that public usage of a product reduces the chance that consumers will buy a store brand, due to the lack of (symbolic) quality. In product categories where risk of public exposure of the product is an important issue, a national brand will outperform a store brand.

\subsubsection{Quality variance and financial risk}

Quality variance within a product category was expected to be positively related to the perceived risk of choosing a low quality product and therefore of losing money. In the data strong support is present for the view that perceived quality variance within a category is related to a negative evaluation of store branded products in that category. This finding leads to the conclusion that when quality variance within a product category is high, it is likely that consumers will choose branded products over store labels, to minimize the financial risks associated with that purchase.

\subsection{Implications}

More and more products, including grocery products, are perceived as a commodity, which adds to the interest in, and importance of private label research. The appeal of traditional brands may wane when consumers become increasingly well informed about products with a commodity-like nature. Renewed interest on the part of national brand manufacturers to produce for private labels is therefore likely (Corstjens and Lal, 2000; Steenkamp and Dekimpe, 1997). The role of supermarkets and grocery stores is currently evolving to one of principally service-focused providers. Providing "One-Stop Shopping" service creates an obvious benefit to consumers (Semeijn and Vellenga, 1995). Offering an increasing variety of "store - certified" goods, with clear labeling, would be part of such a service. The reduction of 
risk, the building of trust, and the time savings afforded to hurried consumers will likely contribute to store loyalty (Dick et al., 1996).

The findings of this study have implications for decision-makers in the grocery business. It is critical that profitable new product opportunities can be identified. Knowing the circumstances in which product categories will benefit a store's private label assortment is crucial (Ailawadi, 2001; Raju et al., 2001). Our study has provided new insights into this matter. New store label products have greatest potential in product categories with small quality variance across brands and low public visibility. Conversely, products in a category with large quality variance and high public visibility are more likely to fail. There appears to be greatest potential for store labels in product categories with low quality variance across brands. In addition, private labels appear more suitable for product categories that are used in a more private environment, rather than for situations in which symbolic qualities play a role.

Dhar and Hoch (1997) point to the fact that retailers can take the lead in the further development of store brands. Developing, nourishing and sustaining a store image can create opportunities to achieve differentiation and positioning relative to other chains and sell profitable store brands. Retailers should therefore focus on aspects, such as store environment, constant quality and value, and customer service.

\subsection{Limitations and suggestions for further research}

Our analysis was based on data collected about four product categories that were available from three retailers, evaluated by a select group of consumers, and collected through a questionnaire that was administered on-line. It would be valuable to further test our model with data from more retailers in different (international) market areas, with a wider range of product categories, or in different sectors, and to include consumer-level variables, as previously suggested by Batra and Sinha (2000). An analysis of heavy store brand users and a comparison of brand pairs (national and private label) has also been mentioned (Ailawadi, 2001; Raju et al., 
2001). A comparison of branded and un-branded store labels is a logical extension as well. The use of scanner date could further substantiate our findings. 
Appendix

\begin{tabular}{lc}
\hline Item & Factor \\
& Loading \\
\hline As a result of the store layout I can easily find what I need. & .70 \\
This store has merchandise available when I need it. & .74 \\
I can easily find in the store the promotions announced on TV, newspapers, & .69 \\
or leaflets. & .64 \\
Employees in this store have the knowledge to answers my questions. \\
I never have problems when I need to return or exchange a product in this
\end{tabular}




\section{References}

Aaker, D.A., Keller, K.L., 1990. Consumer evaluations of brand extensions. Journal of Marketing 54 (1), 27-41.

Ailawadi, K.L., 2001. The retail power-performance conundrum: What have we learned. Journal of Retailing 77, 299-318.

Ailawadi, K.L., Harlam, B.A. (2002), "The effect of store brand share on retail margins: An empirical analysis." Cambridge, MA: Marketing Science Institute.

Baker, J., Grewal, D., Parasuraman, A., 1994. The influence of store environment on quality and store image. Journal of the Academy of Marketing Science 22 (4), 328-339.

Baltas, G., 1997. Determinants of store brand choice: A behavioral analysis. Journal of Product and Brand Management 6 (5), 315-324.

Baron, R.M., Kenny, D.A., 1986. The moderator-mediator variable distinction in social psychological research: Conceptual, strategic and statistical considerations. Journal of Personality and Social Psychology 51 (6), 1173-1182.

Batra, R., Sinha, I., 2000. Consumer-level factors moderating the success of private label brands. Journal of Retailing 72 (2), 175-191.

Bearden, W.O., Etzel, M.J., 1982. Reference group influence on product and brand purchase decisions. Journal of Consumer Research 9, 183-194.

Birtwistle, G., Clarke, I., Freathy, P., 1999. Store image in the uk fashion sector: Consumer versus retailer perceptions. The International Review of Retail, Distribution and Consumer Research 9 (1), 1-16.

Bloemer, J., De Ruyter, K., 1998. On the relationship between store image, store satisfaction and store loyalty. European Journal of Marketing 32 (5/6), 499-513.

Chow, G.C., 1960. Tests of equality between sets of coefficients in two linear regressions. Econometrica 28, 591-605.

Corstjens, M., Lal, R., 2000. Building store loyalty through store brands. Journal of Marketing Research 37 (August), 281-291.

Dabholkar, P.A., Thorpe, D.I., Rentz, J.O., 1996. A measure of service quality for retail stores: Scale development and validation. Journal of the Academy of Marketing Science 24 (1), 3-16.

Davies, G., 1998. Retail brands and the theft of identity. International Journal of Retail and Distribution Management 26 (4), 140-146. 
Dekimpe, M.G., Steenkamp, J.-B.E.M., 2002. Lessons to be learnt from the Dutch privatelabel scene. European Retail Digest 34, 33-36.

DelVecchio, D.S., 2001. Consumer perceptions of private label quality: The role of product category characteristics and consumer use of heuristics. Journal of Retailing and Consumer Services 8, 239-249.

Dhar, S.K., Hoch, S.J., 1997. Why store brand penetration varies by retailer. Marketing Science 16 (3), 208-227.

Dick, A.S., Jain, A.K., Richardson, P., 1995. Correlates of store brand proneness: Some empirical observations. Journal of Product and Brand Management 4 (4), 15-22.

Dick, A.S., Jain, A.K., Richardson, P., 1996. How consumers evaluate store brands. Journal of Product and Brand Management 5 (2), 19-28.

Dunne, D., Narasimhan, C., 1999. The new appeal of private labels. Harvard Business Review (May-June), 41-52.

Fitzell, P., 1992. Private label marketing in the 1990s the evolution of price labels into global brands. New York: Global Book Productions.

Hoch, S.J., Banerji, S., 1993. When do private labels succeed? Sloan Management Review 34 (Summer), 57-67.

Kapferer, J.-N., 1994. Strategic brand management: New approaches to creating and evaluating brand equity. New York: Free Press.

Keller, K.L., 1993. Conceptualizing, measuring, and managing customer-based brand equity. Journal of Marketing 57 (January 1993), 1-22.

Lepir, J., 2001. European private label. Global Cosmetic Industry 169 (2), 72.

MacKinnon, D.P., Dwyer, J.H., 1993. Estimating mediated effects in prevention studies. Evaluation Review 17, 144-158.

MacKinnon, D.P., Warsi, G., Dwyer, J.H., 1995. A simulation study of mediated effect measures. Multivariate Behavioral Research 30 (1), 42-62.

Mazursky, D., Jacoby, J., 1986. Exploring the development of store image. Journal of Retailing 62 (2), 145-165.

Mitchell, V.-W., 2001. Re-conceptualizing consumer store image processing using perceived risk. Journal of Business Research 54, 167-172.

Nandan, S., Dickinson, R., 1994. Private brands: Major brand perspective. Journal of Consumer Marketing 11 (4), 18-28.

Narasimhan, C., Wilcox, R.T., 1998. Private labels and the channel relationship: A crosscategory analysis. Journal of Business 71 (4), 573-600. 
Preacher, K.J., Leonardelli, G.J., 2001. Calculation for the Sobel test: An interactive calculation tool for mediation tests, Retrieved from http://quantrm2.psy.ohiostate.edu/kris/sobel/sobel.htm. Accessed 14/05/2002.

Quelch, J.A., Harding, D., 1996. Brands versus private labels: Fighting to win. Harvard Business Review (January-February), 99-110.

Raju, J.S., Sethuraman, R., Dhar, S.K., 2001. The introduction and performance of store brands. Management Science 41 (6), 957-978.

Richardson, P., Jain, A.K., Dick, A.S., 1994. Extrinsic and intrinsic cue effects on perceptions of store brand quality. Journal of Marketing 58 (October), 28-36.

Richardson, P., Jain, A.K., Dick, A.S., 1996a. Household store brand proneness: A framework. Journal of Retailing 72 (2), 159-185.

Richardson, P., Jain, A.K., Dick, A.S., 1996b. The influence of store aesthetics on the evaluation of private label brands. Journal of Product and Brand Management 5 (1), 19-28.

Semeijn, J., Vellenga, D.B., 1995. International logistics and one-stop shopping. International Journal of Physical Distribution and Logistics Management 25 (10), 26-44.

Sethuraman, R., Cole, C., 1999. Factors influencing the price premiums that consumers pay for national brands over store brands. Journal of Product and Brand Management 8 (4), 340351.

Sobel, M.E., 1982. Asymptotic intervals for indirect effects in structural equations models, in Sociological methodology, S. Leinhart, Ed. San Francisco, CA: Jossey-Bass.

Steenkamp, J.-B.E.M., Dekimpe, M., 1997. The increasing power of store brands: Building loyalty and market share. Long Range Planning 30 (6), 917-930.

Sullivan, M.W., 1990. Measuring image spillovers in umbrella branded products. Journal of Business 63 (1), 309-330.

Thompson, S., 1999. The new private enterprise. Brandweek 40 (18), 36-40.

Van Riel, A.C.R., Lemmink, J., Ouwersloot, H., 2001. Consumer evaluations of brand extensions: Differences between goods and services. Journal of Service Research 3 (3), 220 231.

Wileman, A., Jary, M., 1997. Retail power plays: From trading to brand leadership, strategies for building retail brand value. New York: New York University Press.

Zimmer, M.R., Golden, L.L., 1988. Impressions of retail stores: A content analysis of consumer images. Journal of Retailing 64 (1), 265-293. 


\section{Biographies}

\section{Janjaap Semeijn}

Janjaap Semeijn is Associate Professor of Logistics and Supply Chain Management in the department of Marketing at Maastricht University and Professor of Marketing and Logistics in the Management Sciences department at the Open University Nederland. He received a Master's degree at the American Graduate School of International Management and a PhD. in Logistics Management at Arizona State University (1994). He has published in various international journals, such as Transportation Journal, International Journal of Logistics Management and International Journal of Physical Distribution and Logistics.

\section{Allard C.R. van Riel}

Allard C.R. van Riel is an Assistant Professor in Logistics and Marketing in the department of Marketing at Maastricht University. He holds a degree in Philosophy from the University of Amsterdam and has been active in the International Publishing Industry for almost ten years. His $\mathrm{PhD}$ research focused on Marketing Decision Making under Uncertainty in the area of IT-based Service Innovation (2002). He published in a variety of international journals, such as the Journal of Service Research, the International Journal of Service Industry Management and Total Quality Management, as well as in edited books.

\section{Ana Beatriz Ambrosini}

Ana Beatriz Ambrosini recently completed her Master's degree in International Business in the department of Marketing at Maastricht University. 


\section{Figure Captions}

Figure 1: Conceptual model

Figure 2: Mediation. Source Preacher and Leonardelli (2001) 


\section{Tables}

Table 1: Store image/attitude means

Store brand attitude Store image

\begin{tabular}{llll}
\hline Store Mean & Sd. Mean & Sd.
\end{tabular}

$\begin{array}{lllll}\mathrm{AH} & 4.77 & 1.44 & 5,68 & 1.62\end{array}$

$\begin{array}{lllll}\text { Edah } \quad 4,20 & 1.46 & 4,67 & 1.43\end{array}$

$\begin{array}{lllll}\text { Aldi } & 4,21 & 1.63 & 4,11 & 1.82\end{array}$


Table 2: Correlation matrices for the three retailers

\begin{tabular}{|c|c|c|c|c|c|c|c|c|c|c|c|c|}
\hline \multirow[t]{2}{*}{ Retailer : } & \multicolumn{4}{|c|}{ Albert Heijn } & \multicolumn{4}{|c|}{ Edah } & \multicolumn{4}{|c|}{ Aldi } \\
\hline & $\begin{array}{c}\text { Store brand } \\
\text { attitude }\end{array}$ & $\begin{array}{l}\text { Store } \\
\text { image }\end{array}$ & $\begin{array}{c}\text { Functional } \\
\text { risk }\end{array}$ & $\begin{array}{c}\text { Psychosocial } \\
\text { risk }\end{array}$ & $\begin{array}{c}\text { Store brand } \\
\text { attitude }\end{array}$ & $\begin{array}{l}\text { Store } \\
\text { image }\end{array}$ & $\begin{array}{c}\text { Functional } \\
\text { risk }\end{array}$ & $\begin{array}{c}\text { Psychosocial } \\
\text { risk }\end{array}$ & $\begin{array}{c}\text { Store brand } \\
\text { attitude }\end{array}$ & $\begin{array}{l}\text { Store } \\
\text { image }\end{array}$ & $\begin{array}{c}\text { Functional } \\
\text { risk }\end{array}$ & $\begin{array}{c}\text { Psychosocial } \\
\text { risk }\end{array}$ \\
\hline $\begin{array}{l}\text { Store brand } \\
\text { attitude }\end{array}$ & 1 & & & & 1 & & & & 1 & & & \\
\hline $\begin{array}{l}\text { Store } \\
\text { image }\end{array}$ & $.385 * *$ & 1 & & & $.430 * *$ & 1 & & & $.446^{* *}$ & 1 & & \\
\hline $\begin{array}{l}\text { Functional } \\
\text { risk }\end{array}$ & $-.358^{* *}$ & $-.106^{*}$ & 1 & & $-.319 * *$ & $-.127 * *$ & 1 & & $-.178 * *$ & .028 & 1 & \\
\hline $\begin{array}{l}\text { Psychosocial } \\
\text { risk }\end{array}$ & $-.291 * *$ & $-.238 * *$ & .021 & 1 & $-.264 * *$ & $-.291 * *$ & -.011 & 1 & $-.244 * *$ & $-.333 * *$ & $-.116^{* *}$ & 1 \\
\hline $\begin{array}{l}\text { Financial } \\
\text { risk }\end{array}$ & $-.479 * *$ & -.085 & $.163 * *$ & $.203 * *$ & $-.498 * *$ & $-.141 * *$ & $.256^{* *}$ & .049 & $-.351 * *$ & $-.121 * *$ & .056 & .080 \\
\hline
\end{tabular}

**Correlation is significant at the 0.01 level

*Correlation is significant at the 0.05 level 
Table 3: Results of the analyses

\begin{tabular}{|c|c|c|c|c|c|c|c|c|}
\hline & \multirow{2}{*}{$\begin{array}{l}\text { Chow test } \\
\text { statistic }\end{array}$} & \multirow[t]{2}{*}{ F-value } & \multicolumn{3}{|c|}{ Discount chain } & \multicolumn{3}{|c|}{ Grocery stores } \\
\hline & & & \multicolumn{3}{|c|}{$\begin{array}{l}\text { Adj. } \mathrm{R}^{2}=.33 \mathrm{~F}=65.997 \\
\text { Sig. }=.000\end{array}$} & \multicolumn{3}{|c|}{$\begin{array}{l}\text { Adj. } \mathrm{R}^{2}=.45 \mathrm{~F}=216.276 \\
\text { Sig. }=.000\end{array}$} \\
\hline Independent variable & & & Beta & $t$ & Sig. & Beta & $t$ & Sig. \\
\hline Constant & n. a. & & 6.365 & 34.333 & .000 & 6.394 & 60.538 & .000 \\
\hline Store image & 9.90 & 2.61 & .378 & 10.232 & .000 & .330 & 13.734 & .000 \\
\hline Functional risk & 9.57 & 2.61 & -.142 & -3.938 & .000 & -.220 & -9.315 & .000 \\
\hline Psychosocial risk & 7.56 & 2.61 & -.151 & -4.088 & .000 & -.145 & -6.115 & .000 \\
\hline Financial risk & 9.13 & 2.61 & -.303 & -8.427 & .000 & -.288 & -16.256 & .000 \\
\hline
\end{tabular}


Table 4: Status of the propositions

\begin{tabular}{llll}
\hline Nr. & Proposition & \multicolumn{2}{c}{ Proposition status } \\
\hline 1 & $\begin{array}{l}\text { There will be a direct positive relationship between perceived store image and } \\
\text { consumer attitude towards store branded products. }\end{array}$ & $\sqrt{ }$ & $\begin{array}{l}\text { Discount } \\
\text { chain }\end{array}$ \\
\hline 2 & $\begin{array}{l}\text { Consumer attitude towards a store branded product is inversely related to the } \\
\text { functional risk associated with the perceived difficulty for the retailer to } \\
\text { produce that product. }\end{array}$ & $\sqrt{ }$ & $\sqrt{ }$ \\
\hline $2 \mathrm{a}$ & $\begin{array}{l}\text { The effect of store image on consumer attitude towards a store branded product } \\
\text { is mediated by the functional risk associated with the perceived difficulty for } \\
\text { the retailer to produce that product. }\end{array}$ & $\sqrt{ }$ & $\mathrm{X}$ \\
\hline 3 & $\begin{array}{l}\text { Consumer attitudes towards a store branded product are inversely related to the } \\
\text { perceived psychosocial risk associated with the usage of that product. } \\
\text { The relationship between store image and consumer attitude towards a store } \\
\text { branded product is mediated by the perceived psychosocial risk of usage. } \\
\text { Consumer attitude towards a store branded product is inversely related to the } \\
\text { perceived financial risk associated with quality variance in the product } \\
\text { category. }\end{array}$ & $\sqrt{ }$ & $\sqrt{ }$ \\
& & $\sqrt{ }$ \\
\end{tabular}


Figure 1

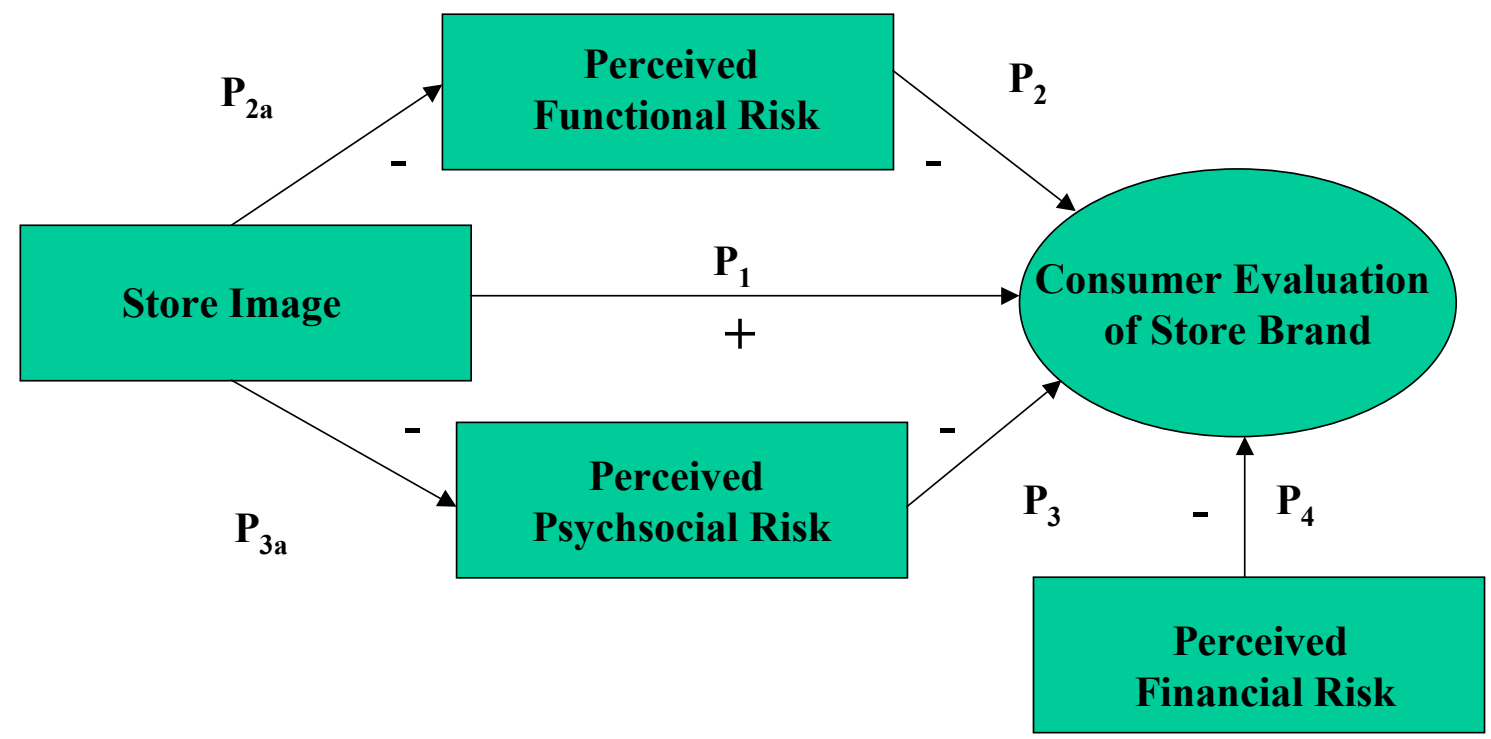


Figure 2

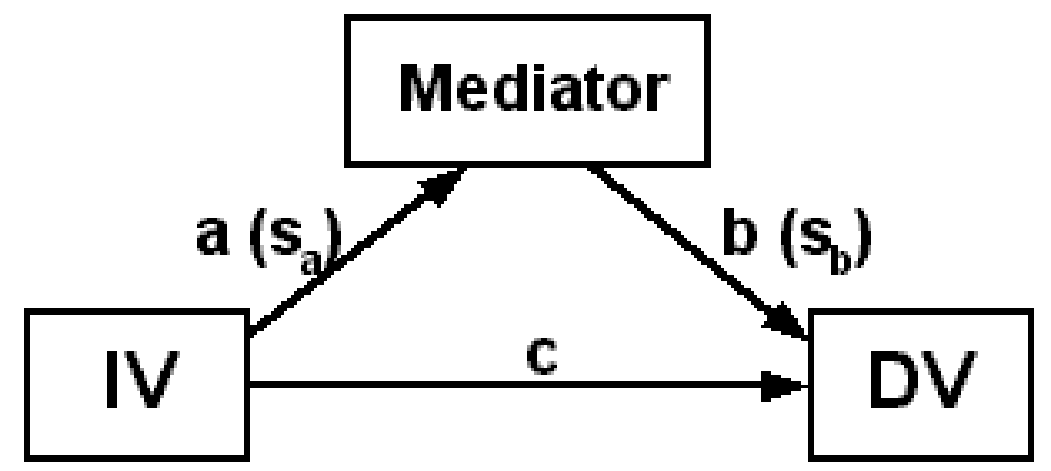

